\title{
Entre o culto e o popular: diálogo sobre a arte latinoamericana ${ }^{1}$
}

Between the cultured and the popular: dialogue about the latin american art

Thaís de Oliveira ${ }^{2}$

"El arte se queda siempre a medio camino entre el objeto y el lenguaje." Lévi-Strauss

\begin{abstract}
RESUMO
O presente ensaio tem como principal objetivo analisar a influência das culturas europeias e norte-americanas sobre a cultura latino-americana, principalmente no contexto da globalização. Durante muito tempo existiu uma subdivisão entre as culturas, onde países do "centro" - por exemplo, países da Europa e os Estados Unidos - eram vistos como o "berço" da cultura culta e dominante, e em contrapartida, os países da "periferia" - no caso deste estudo, os países da América Latina - eram vistos como o "berço" da cultura popular, cultura esta que não representava a "elite" desta região. Por esta razão, pretende-se verificar se no contexto globalizador existe um diálogo entre estas culturas e de que maneira isso ocorre.
\end{abstract}

Palavras-chave: Cultura; América Latina; Globalização.

\begin{abstract}
The present paper has as main objective to analyze the influence of the European and North American cultures on the Latin American culture - mainly in the Globalization context. For a long time there was a subdivision between the cultures, where countries that were part of the "center" - for instance, countries of Europe and the United States - were seen as the "cradle" of the cultured and dominant culture, and in the opposite, the countries part of the "periphery" - in the case of this study, the countries of Latin America were seen as the "cradle" of the popular culture, culture that did not represent the "elite" of this region. For this reason, we intend to verify if in the globalizing context there is a dialogue between these cultures and how this relation happens.
\end{abstract}

Key-words: Culture; Latin America; Globalization.

\footnotetext{
${ }^{1}$ Artigo recebido em 18 de dezembro de 2013 e aprovado em 02 de fevereiro de 2014.

2 Mestranda em Integração da América Latina pelo Programa de Pós-Graduação em Integração da América Latina da Universidade de São Paulo - (PROLAM), Especialista em Direito Internacional e Econômico pela Universidade Estadual de Londrina (UEL) e bacharel em Turismo pela Faculdade Estácio de Sá de Ourinhos - SP (FAESO). São Paulo - Brasil. Email: thais.de.oliveira@usp.br.

Conjuntura Global, Curitiba, Vol.2, n.4, out./dez., 2013, p. 222-229.
} 
Ao indagarmos sobre o que é arte, podemos pensá-la como sendo a arquitetura, a escultura, a pintura, a música, a poesia entre outros. Entretanto, Tolstoi nos adverte que, para que possamos ter uma definição correta do que é arte, é necessário reconhecêla como uma das condições da vida humana. Podemos pensar a arte como um elo de comunicação entre os homens. Para Kagan (2012, p.19) "a arte é comparável com o conhecimento em geral, com todo o universo dos valores, com a comunicação como tal, já que o conhecimento é produto da criação artística como tipo de atividade, de um tipo em que se integram organicamente todos os demais". Sabemos que quando pensamos em arte, automaticamente somos levados a pensar na arte culta, nas mais diversas manifestações surgidas na Europa, o que por muitos anos foi definida como a verdadeira arte, e servia como modelo para avaliar o que poderia ser considerada uma obra de arte ou não.

Entretanto, embora em uma obra de arte o estético seja importante, devemos ponderar também o sentimento do artista quando elaborou a mesma, pois uma obra de arte carrega signos que estão relacionados à realidade, à identidade e à história deste artista. A partir do fim do século XX, várias mudanças e processos complexos começaram a acontecer. Tais processos cruzaram fronteiras nacionais e estabeleceram contatos com outras comunidades e organizações criando novas combinações que permitiram que o mundo estivesse mais integrado, este fenômeno pode ser entendido por Globalização. A globalização causou impactos em muitos campos, como o da política, economia, comércio e cultura, gerando mudanças em suas estruturas e principalmente nas sociedades, que vêm se modificando constante e permanentemente, tornando-se cada vez modernas e apresentando distinções em relação às sociedades tradicionais. Neste sentido Giddens ${ }^{3}$ (1990, p.37-38) apud Hall (2011, p. 15) argumenta que:

\footnotetext{
Nas sociedades tradicionais, o passado é venerado e os símbolos são valorizados porque contêm e perpetuam a experiência de gerações. A tradição é um meio de lidar com o tempo e o espaço, inserindo qualquer atividade ou experiência particular na continuidade do passado, presente e futuro, os quais, por sua vez, são estruturados por práticas sociais recorrentes.
}

\footnotetext{
${ }^{3}$ GIDDENS, Anthony. The Consequences of Modernity. Cambridge: Polity Press, 1990. 
No que tange à modernidade, vale destacar que sua definição vai muito mais além da experiência em relação às mudanças que ocorreram, ela é uma forma de se refletir a vida, onde "as práticas sociais são constantemente examinadas e reformadas à luz das informações recebidas sobre aquelas próprias práticas, alterando, assim, constitutivamente, seu caráter". (ibid., p.37-38). Em uma sociedade global o indivíduo passa a constituir e a desenvolver novas condições sociais, econômicas, políticas e culturais, que são influenciadas pelo exterior. Segundo Ianni (2005, p.113):

As referências habituais na constituição do indivíduo, compreendendo língua, dialeto, religião, seita, história, tradições, heróis, santos, monumentos, ruínas, hinos, bandeiras e outros elementos culturais, são complementadas, impregnadas ou redescobertas por padrões, valores, ideais, signos e símbolos em circulação mundial.

Neste sentido, podemos dizer que com a globalização, músicas, idiomas, mercadorias e informações de todos os lugares, passaram a integrar um mesmo espaço, e estão acessíveis à maior parte da população mundial. No processo de globalização devemos mencionar a relação entre os centros e as periferias, onde países “desenvolvidos" (centros) - exemplo, Estados Unidos e Inglaterra - possuíam vantagens, principalmente comerciais, em relação aos países "subdesenvolvidos" (periferias) exemplo, países integrantes da América Latina - que eram submissos aos primeiros.

Em relação à arte, podemos afirmar que também existia esta subdivisão, onde a arte culta, ou a que era considerada arte para a "elite", pertencia ao centro. 0 que não era considerada arte para esta parcela da população, como por exemplo, a arte popular, pertencia à periferia. Conforme leciona Escobar (1997, p. 17) ${ }^{4}$ :

Existe um centro e suas periferias, um lado de dentro e um lado de fora, domínios próprios e alheios. Existem fronteiras cujo traço constitui um eixo em torno do qual se articularão diversos pares de oposições binárias. E existem

\footnotetext{
${ }^{4}$ Existe un centro y sus periferias, un adentro y un afuera, dominios propios y ajenos. Existen fronteras cuyo trazo constituye un eje en torno al cual se articularán diversos pares de oposiciones binarias. Y existen demarcaciones nacionales que acotan acervos identitarios distintivos. [...] Las culturas de países periféricos dependen de las de las submetrópolis regionales. Así también, las culturas marginales (rurales, indígenas, suburbanas) están subordinadas a las señales emitidas desde las ciudades capitales en un proceso de sucesivas mediaciones a través de las cuales se ejerce escalonadamente el poder central. (En cada caso, será función del arte expresar y sintetizar esas oposiciones: resolverlas en una instancia superior capaz de asumir los momentos enfrentados).
} 
demarcações nacionais que delimitam acervos identitários distintos. [...] As culturas de países periféricos dependem das culturas das submetrópoles regionais. Assim também, as culturas marginais (rurais, indígenas, suburbanas) estão subordinadas aos sinais emitidos a partir das cidades capitais em um processo de sucessivas mediações através das quais se exerce gradualmente o poder central. (Em cada caso, será função da arte expressar e sintetizar essas oposições: resolve-las em uma instância superior capaz de assumir os momentos enfrentados). [tradução nossa].

A América Latina sofreu influência europeia na música, vestimenta, idioma, gastronomia, entre outros, e muitas vezes a elite desta região (criollo) buscava produtos europeus para utilização própria, pois este feito representava para eles status. Assim, muitas manifestações artísticas europeias foram inseridas nesta região, o que ocasionou o início de um processo de hibridação cultural. Contudo, muitas vezes, tais manifestações se sobressaíam às tradições regionais e nacionais. 0 que era de fato algo "negativo", pois, os costumes locais ficavam muitas vezes ocultos, ou eram até mesmo esquecidos, pelo fato de não serem considerados cultos, e sim, populares. Ao definir a arte latino-americana Escobar (1997, p.20) ${ }^{5}$ diz que:

A arte da América Latina já não é considerada nem como o santuário de essências exteriores à história nem como o filho feliz de grandes sínteses conciliadoras. É compreendida como um enredo promíscuo, uma confusão de formas alheias e próprias, cultas e populares, tradicionais e modernas. [tradução nossa].

Partindo desta premissa surge uma grande dúvida, existe uma arte genuinamente Latino Americana? Uma vez que a região possui grandes influências culturais, mormente europeias e norte-americanas? Podemos observar tal fato pelos escritores latino-americanos que estabeleceram suas residências definitivamente ou por um determinado período de tempo na Europa, e em suas obras, raramente encontramos elementos nacionais e/ou regionais, senão alienígenas; artistas plásticos e pintores que estudaram nas melhores escolas europeias e, ao retornar aos seus países de origem, exibem obras com influências externas e que dificilmente retratam a realidade local, e sim a que eles viveram naqueles países.

\footnotetext{
${ }^{5}$ El arte de Latinoamérica ya no es considerado ni como el santuario de esencias exteriores a la historia ni como el hijo feliz de grandes síntesis conciliadoras. Es comprendido como un enredo promiscuo, un entrevero de formas ajenas y propias, cultas y populares, tradicionales y modernas.
} 
Podemos mencionar igualmente, a influência norte-americana na região, principalmente no que se refere à música, cinema, vestimenta e gastronomia. Os filmes exibidos na América Latina são, na maioria das vezes, mega produções hollywoodianas, que abordam temas que, geralmente, não têm relação com o contexto que vivemos. As músicas também possuem grande influência norte americana, e infelizmente, na atual conjuntura, se perguntarmos a um adolescente latino americano quem é/foi Bob Marley ele saberá responder, mas se indagarmos quem é/foi Mercedes Sosa, provavelmente, não saberá nos dizer. Em relação à gastronomia vemos da mesma maneira esta presença, uma vez que as redes de fast food possuem grande predominância na região. Se perguntarmos a uma criança onde ela quer comer ao sair de casa, provavelmente ouviremos Mc Donald's. Sabemos que estas redes atraem não apenas às crianças, mas o público em geral. Porém dificilmente uma pessoa saberá, pelo menos aqui no Brasil, como é a sopa Paraguaia.

O maior problema encontrado nesta região é a falta de interação e integração cultural, peguemos o MERCOSUL como exemplo, que foi constituído como um Mercado Comum, e neste sentido, deveria contemplar as quatro liberdades que permeiam o modelo integracionista de Mercado Comum: a livre circulação de pessoas, serviços, capitais e bens. Porém, não é o que acontece na prática, pois o MERCOSUL, ainda não deixou o status de União Aduaneira, e que é, diga-se de passagem, "imperfeita”. No que concerne à livre circulação de bens, poderíamos incluir os bens culturais, apresentações e manifestações artísticas de todas as naturezas, obras literárias, músicas, gastronomias, e enfim, proporcionar de fato o intercâmbio cultural entre os países vizinhos, e permitir que suas culturas sejam contempladas, pois estamos tão próximos, e conhecemos tão pouco dos mesmos.

Quando falamos de cultura regional, devemos fazer menção também às culturas de origem pré-colombianas que foram, de certa maneira, solapadas e substituídas pela cultura ocidental, e ficaram ocultas por muito tempo, uma vez que a arte latinoamericana ficou à mercê da influência das culturas centrais. Entretanto, ainda que a internacionalização da arte ocasionasse a imposição de conceitos existentes nas culturas centrais às culturas periféricas, gerando uma total dominação cultural, as sociedades latino-americanas sentiram a necessidade de resgatar suas raízes, suas tradições e culturas populares. (ESCOBAR, 2009) 
Como afirma Morín (2003), diante do processo de globalização e internacionalização, em todas as partes acontece uma volta às origens, uma luta contra a perda de identidade e autenticidade cultural. Ainda que o processo de hibridação exista na localidade, afinal são várias culturas dividindo o mesmo espaço, é necessário que haja a aceitação da cultura o outro, e que as culturas se complementem. Embora não seja considerado por muitos como arte, o artesanato tem um grande papel neste cenário, e deve ser reconhecido, pois por meio dele, as tradições, principalmente indígenas, podem ser conhecidas, não apenas em âmbito local e/ou regional, mas também internacional. (CANCLINI, 1982)

Escobar (2008) afirma que existe uma divisão entre a grande arte, que é a que tem maior reconhecimento e é dominante; e a arte menor - o artesanato - que é colocada em posição de desvantagem, onde os valores criativos da cultura dominante se destacam e de certa forma desestimam as populares. Como mencionado inicialmente, uma vez que a arte é o elo de comunicação entre os homens, neste sentido, o artesanato exerce esta função com maestria, pois por meio dos produtos confeccionados, podemos conhecer a história e as tradições dos artesãos, que são na maioria das vezes - na América Latina descendentes dos povos pré-colombianos.

0 artesanato tem conquistado seu espaço, e está sendo valorizado, não apenas como mercadoria a ser comercializada, mas também como uma maneira de transmitir às presentes e futuras gerações um pouco da história de seus ancestrais. No México, por exemplo, o governo tem incentivado a produção do mesmo, para que a tradição não desapareça, além disso, peças são exibidas em museus na Europa, e produtos são comercializados no exterior. (CANCLINI, 1982)

Sabemos que a globalização trouxe muitos benefícios para a população mundial, como a facilidade de comunicação, os avanços tecnológicos em diferentes áreas, e também uma maior aproximação de pessoas, que dividem o mesmo espaço e compartilham culturas diferentes. Entretanto, na América Latina, talvez a forte influência externa na seara cultural, tenha, de certa maneira, "ocultada" a riqueza cultural que a mesma possui. É certo que não podemos falar de um único tipo de cultura, ou uma cultura genuinamente latino-americana, uma vez que a América Latina é composta de uma vasta e rica miscigenação de povos, culturas e tradições. 
Apesar de vários esforços no que concerne ao resgate das tradições e culturas latino-americanas atualmente, sentimos que ainda existe uma lacuna a ser preenchida na seara cultural desta região, ou seja, uma maior valorização e difusão desta cultura entre os países latino-americanos, bem como externamente. 0 cinema latino-americano, por exemplo, vem surpreendendo pela sua qualidade, mas poucos têm acesso e conhecimento ao/do mesmo. 0 mesmo acontece com as obras literárias, a música e a gastronomia, e vale destacar que estas manifestações culturais representam de alguma maneira, a nossa realidade.

Acreditamos que a interação com outras culturas - como a europeia e norteamericana aqui mencionadas - seja importante para que outras realidades e outras representações artísticas sejam conhecidas, mas acreditamos igualmente, que a cultura latino-americana deva ser levada até estas outras culturas, e, desta maneira, um maior intercâmbio ocorra. Iniciativas neste sentido já estão sendo realizadas, algumas manifestações artísticas - ainda que de maneira lenta - estão cruzando fronteiras e sendo exibidas em outros continentes.

Embora este ensaio seja apenas uma reflexão, por considerarmos este tema relevante, pretendemos seguir investigando sobre o mesmo, e futuramente apresentar dados mais concretos em relação à recepção e à distribuição da arte latino-americana tanto em países latino-americanos quanto em países não pertencentes a esta região. Assim, esperamos que da mesma maneira que a cultura Europeia e a Norte Americana influenciaram e "conquistaram" a América Latina, a cultura latino-americana - que é tão rica - seja compartilhada com outros países, e também conquiste e influencie seus receptores.

\section{REFERÊNCIAS}

CANCLINI, Néstor Garcia. As Culturas Populares no Capitalismo. São Paulo: Editora Brasiliense, 1982.

ESCOBAR, Ticio. El Arte en los Tiempos Globales. Asunción: Editorial Don Bosco, 1997. . El mito del arte y el mito del pueblo. Santiago: Ediciones Metales Pesados, 2008. 
. El marco incompleto. p. 93-105. In: Proceedings Aica Congress 2007. São Paulo, 2009.

HALL, Stuart. A identidade cultural na pós-modernidade. 11.ed. Rio de Janeiro: DP\&A, 2011.

IANNI, Octávio. A Sociedade Global. 12.ed. Rio de Janeiro: Civilização Brasileira, 2005.

KAGAN, Moisei S.. A Arte no Sistema da Atividade Humana. p. 12-25. In: Arte e Cultura da América Latina.v. 27 (1ํo sem. 2012). São Paulo: CESA: Terceira Imagem, 2013.

MORIN, Edgar. La Cultura en la Globalización. Diario Clarín, 18 de Marzo de 2003, Año VII, no 2542. Disponível em: www.pensamientocomplejo.com.ar. Acesso em: 20 de Setembro de 2012.

TOLSTOI, León. ¿Qué es el arte?. Disponível em: www.mural.uv.es/aruizta2/tolstoiarte.pdf. Acesso em: 31 de Maio de 2013. 